\title{
Temporally Correlated Expression of nAChR Genes During Development of the Mammalian Retina
}

\author{
FRANK HOOVER AND DANIEL GOLDMAN* \\ Mental Health Research Institute and Department of Biological Chemistry, University of Michigan, \\ Ann Arbor, MI 48109, U.S.A.
}

\author{
(Received Houston 22 February 1991 and accepted in revised form 8 July 1991)
}

\begin{abstract}
In situ hybridizations and RNase protection assays have been used to characterize nicotinic acetylcholine receptor (nAChR) gene expression in the developing and adult rat retina. At the earliest time examined (embryonic day 13) a low level of $\alpha-3$ and $\beta-4$ gene expression could be detected. During the next $48 \mathrm{hr}$ there was a dramatic induction of the $\alpha-3, \alpha-4, \beta-2, \beta-3$ and $\beta-4$ genes in the recently differentiated retinal ganglion cells. By post-natal day 4 we detected nAChR gene expression in the inner nuclear layer. In the adult retina, in situ hybridizations showed these genes are expressed by cells residing in the ganglion and inner nuclear layers. These results suggest a common regulatory mechanism for the induction of $\mathrm{nAChR}$ expression in retinal ganglion cells during development. In addition, the variety of $n A C h R$ genes expressed in the retina imply a relatively large number of different types of $n A C h R s$ can be expressed by these cells.

Key words: retina; development: nAChR; gene expression; ganglion cell.
\end{abstract}

\section{Introduction}

A central issue in neurobiology is determining the molecular mechanisms by which specific cell types arise in the developing nervous system. One approach to this question is to identify genes whose expression is unique to a particular cell type. Characterizing the mechanisms by which these genes are developmentally regulated should shed light on the mechanisms involved in cell differentiation. We have decided to take this approach using the retina as a model system. The retina provides an excellent system for studying central nervous systems (CNS) development and cell determination. The reasons for this include: the well defined stages of retinal cell differentiation; the continued post-natal mitosis of retinal precursors; the laminar organization of the various classes of retinal neurons; and its accessibility to experimental manipulations. In addition, most of the retinal neurotransmitters have been identified and the six major classes of retinal neurons have been well described (reviewed in Massey and Redburn, 1987). Each class of neuron has several subtypes, which brings the total number of different retinal neurons to around 60 .

The retina develops from the anterior aspect of the neural tube. Neuroepithelial precursors proliferate to eventually give rise to the entire retina (reviewed by Barnstable, 1987). After undergoing terminal mitosis at the ventricular zone, these cells (retinal neuroblasts) migrate to their final position. Developmental studies indicate that these neuroblasts are multipotential

\footnotetext{
* For correspondence at: ITniversity of Michigan. Mental Health Research Institute, 205 Zina Pitcher Place. Ann Arbor, MI 48109. U.S.A.
}

$0014-4835 / 92 / 040561+11 \$ 03.00 / 0$
(Turner and Cepko, 1987 ; Turner, Snyder and Cepko, 1990; Wetts and Fraser, 1988; Holt et al., 1988) and become committed to their phenotype about the time they withdraw from the cell cycle (Adler and Hatlee, 1989). The molecular mechanisms by which uncommitted cells differentiate into various retinal neurons are not known, although both genetic and epigenetic events are likely involved. It is clear, however, that cell-type specific genes must be induced in these cells as they differentiate. Understanding the mechanisms responsible for regulating the expression of these genes during development should further our understanding of the differentiation process.

One set of such genes are those encoding nAChRs. These receptors are encoded by a family of related genes whose membership includes a variety of ligandbinding $\alpha$-subunits and structural $\beta$-subunits (reviewed by Leutje, Patrick and Seguela, 1990). Expression studies indicate that a functional neural nAChR can often be formed by co-expressing a single $\alpha$-subunit with a particular $\beta$-subunit.

Electrophysiological assays indicate that rat retinal ganglion cells express nAChRs (Lipton. Aizenman and Loring. 1987). In the neuropil of the innerplexiform layer some of these receptors may mediate communication between cholinergic amacrine cells (Masland, Mills and Hayden, 1984) and directionally sensitive ganglion cells (Ariel and Daw, 1982a, b). In addition, immunohistochemical staining and in situ hybridizations have shown that nAChRs and the genes encoding them are expressed in the adult vertebrate retina (Swanson et al., 1987: Cauley, Agranoff and Goldman, 1989, 1990; Wada et al., 1989; Matter, Matter-Sadzinski and Ballivet, 1990). However, neither the number of different types of 
nAChRs, nor the variety of cells that express these molecules in the retina is known. In addition, little is known about when these genes begin to be expressed during retinal development. Here we charactcrize the expression of the $\alpha-2, \alpha-3, \alpha-4, \beta-2, \beta-3$ and $\beta-4$ nAChR subunit-encoding gencs in the developing and adult rat retina and show their expression to be temporally correlated during retinal ganglion cell development.

\section{Materials and Methods}

Probes

nAChR cDNA clones (Fig. 1) were kindly provided by Drs Stephen Heinemann, Jim Patrick and associates (The Salk Institute, La Jolla, CA). A 1·1-kb BamH I/ Acc I fragment of the $\alpha-2$ cDNA (Wada et al., 1988) was subcloned into the Bluescript $\mathrm{SK}(+)$ vector (Stratagene, La Jolla, CA) and linearized with BamH I. The $\alpha-3$ cDNA (Boulter et al., 1986) was subcloned into the pSP73 vector (Promega, Madison, WI) and linearized with either Acc I or Xho I. The $\alpha-4$ cDNA (Boulter et al., 1987; Goldman et al., 1987) was subcloned into the pSP73 vector and linearized with Cla I or EcoR I. A 1.4-kb EcoR I/Pvu II fragment of the $\beta-2$ cDNA (Deneris et al., 1988) was subcloned into pSP73 and linearized with Bgl II. The 3' $1 \cdot 85-\mathrm{kb}$ EcoR I fragment of the $\beta-3$ cDNA clone (Deneris et al., 1989) was subcloned into the Bluescript SK( - ) vector and was linearized with Cla I. The $\beta$-4 cDNA (Duvoisin et al., 1989) was linearized with EcoR I. A pSP65 plasmid harboring the human U1 gene, encoding a small nuclear RNA, was kindly provided by $\mathrm{Dr}$ J. Gregory Howe (Howe and Steitz, 1986). This plasmid was linearized with Hind III. Antisense $\left[{ }^{35} \mathrm{~S}\right] \mathrm{RNA}$ probes were generated from these linearized constructs by run-off transcription using either SP6 $(\alpha-3, \mathrm{U} 1)$, T3 $(\beta-3)$ or T7 $(\alpha 2, \alpha-4, \beta-2, \beta-4)$ promoters. Probes were hydrolyzed with $100 \mathrm{~mm}$ $\mathrm{Na}_{2} \mathrm{CO}_{3} / \mathrm{NaHCO}_{3}(\mathrm{pH} 10 \cdot 2)$ to an average size of 200 nucleotides prior to in situ hybridization (Cox et al., 1984).

\section{In Situ Hybridization}

Adult male, pust-natal and fetal Sprague-Dawley rats were used for this study. Animals were anesthetized with ether before death, and the retinas were removed and placed into a $4 \%$ paraformaldehyde/PBS [10 $\mathrm{mM} \mathrm{NaPO}_{4}$ (pI 7.2), $145 \mathrm{~mm} \mathrm{NaCl}$ ] solution at $4^{\circ} \mathrm{C}$. After fixing the tissue for $2 \mathrm{hr}$, the retinas were removed and cryoprotected in a $30 \%$ sucrose/PBS solution at $4^{\circ} \mathrm{C}$ for approximately $2-3 \mathrm{hr}$. The retinas were then mounted into a mold filled with OCT (Tissue Tek, Elkhardt, IN), and frozen with dry ice. Frozen sections were cut $15 \mu \mathrm{m}$ thick on a cryostat and collected on poly-L-lysine subbed slides. The sections were then dried in a $80^{\circ} \mathrm{C}$ vacuum oven for $20 \mathrm{~min}$ and stored at $-20^{\circ} \mathrm{C}$. Prior to hybridization the sections were hydrated through graded alcohols. rinsed in 2X SSC $(0.3 \mathrm{M} \mathrm{NaCl}, 0.03 \mathrm{M} \mathrm{Na}$-citrate, $\mathrm{pH} 7 \cdot 4)$, and digested with Proteinase $\mathrm{K}\left(10 \mu \mathrm{g} \mathrm{ml}^{-1}\right)$ in $0.1 \mathrm{M}$ Tris ( $\mathrm{pH} \mathrm{7.2)}$ ) and $0.05 \mathrm{M}$ EDTA for $15 \mathrm{~min}$ at $37^{\circ} \mathrm{C}$. The sections were then acetylated with $0.25 \%$ acetic anhydride in $0 \cdot 1 \mathrm{M}$ triethanolamine $(\mathrm{pH} 8 \cdot 0)$ for $10 \mathrm{~min}$ at room temperature. before dehydrating through graded alcohols. Approximately $25 \mu \mathrm{l}$ of hybridization solution $[10 \mathrm{mM}$ Tris $(\mathrm{pH} 7 \cdot 4)$. $0.3 \mathrm{M} \mathrm{NaCl}, 1 \mathrm{~mm}$ EDTA, $10 \%$ Dextran sulfate, $0 \cdot 1 \mathrm{~mm}$ DTT] containing $50000 \mathrm{cpm} \mu \mathrm{l}^{-1}$ of radiolabeled $\left[{ }^{35} \mathrm{~S}\right] \mathrm{CRNA}$ probe was placed onto each section. The sections were coverslipped, and the edges of the coverslips sealed with glue. The slides were then placed into a humid chamber and incubated for $12-18 \mathrm{hr}$ at $65^{\circ} \mathrm{C}$. Following hybridization, the glue was removed, the slides were placed in a rack and the coverslips were floated off by rinsing three times for $10 \mathrm{~min}$ in 2XSSC. Slides were then immersed in $50 \%$ formamide. 2XSSC (pH 7.4), and $10 \mathrm{~mm}$ DTT at $55^{\circ} \mathrm{C}$ for $30 \mathrm{~min}$. Single-stranded RNA still binding to the section was removed by digestion with RNase A $\left(50 \mu \mathrm{g} \mathrm{ml}^{-1}\right)$ in $10 \mathrm{~mm}$ Tris $(\mathrm{pH} 7 \cdot 5), 0.5 \mathrm{M} \mathrm{NaCl}$, and $1 \mathrm{~mm}$ EDTA. Sections were then rinsed in $10 \mathrm{~mm}$ Tris (pH 7.5), $0.5 \mathrm{M} \mathrm{NaCl}$, and $1 \mathrm{~mm}$ EDTA, for $30 \mathrm{~min}$ at $65^{\circ} \mathrm{C}$ and dehydrated through graded alcohols containing $0 \cdot 4 \mathrm{~m}$ ammonium acetate. After air drying, the sections were dipped in photographic emulsion [NTB-2 (Kodak), 1:1 dilution with water], and dried in a light-tight container. The sections were exposed for 4 days before developing. The sections were then stained with Hematoxylin and Eosin B, dehydrated and differentiated through graded alcohols and xylenes. The sections were then coverslipped and viewed with a Zeiss Axiophot microscope using bright and dark field optics. Retinal cells were considered to express nAChR mRNA above background if they possessed greater than five silver grains clustered over their nuclei. The percentage of cells expressing nAChR genes in the ganglion cell layer were quantitated by counting the number of positively hybridizing cells and dividing by the total number of cells in this layer. Reported values are averages from four to five different retinal sections.

\section{RNase Protection Assays}

Total RNA was isolated from retinas as previously described (Chirgwin et al., 1979; Goldman et al., 1985). Radiolabeled antisense RNA probes were prepared by run-off transcription of linearized vectors harboring the nAChR $\alpha-2$ and $\beta-4$ cDNAs. The $\alpha-2$ cDNA was restricted with Alu I, which resulted in a 350-nucleotide probe (excluding vector sequences). These nucleotides encode amino acids spanning the cytoplasmic domain. The $\beta-4$ cDNA was linearized with Xba I. This yielded a 409-nucleotide probe (excluding vector sequences) containing $3^{\prime}$ untrans- 


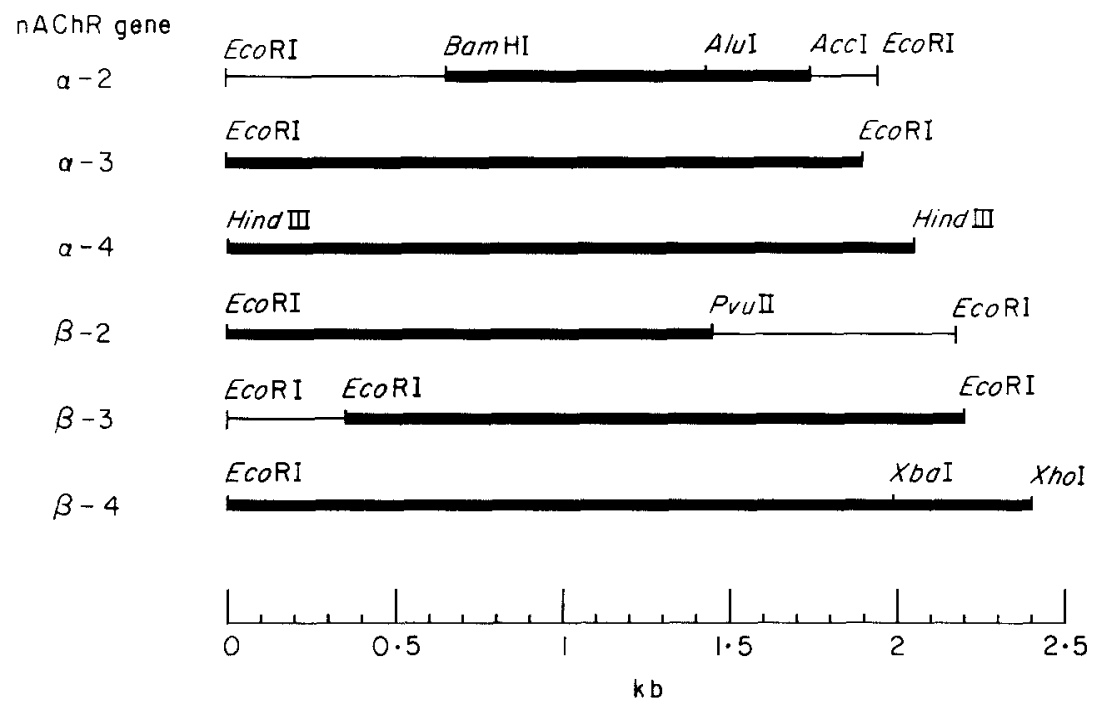

FIG. 1. Line diagram of $n A C h R$ cDNAs and probes used for in situ hybridizations. The thin horizontal line represents the nAChR cDNA portion of the recombinant plasmids described in Materials and Methods. The closed boxes represent portions of the cDNA used to generate probes for in situ hybridizations.

lated sequence. The hybridization reaction contained $25-78 \mu \mathrm{g}$ total retinal RNA, approximately $500000 \mathrm{cpm}$ of radiolabeled [ $\left.{ }^{32} \mathrm{P}\right] \mathrm{cRNA}$ probe, $50 \%$ formamide, $40 \mathrm{~mm}$ PIPES ( $\mathrm{pH} \mathrm{6.7)}, 750 \mathrm{mM} \mathrm{NaCl}$, and $1 \mathrm{~mm}$ EDTA. After annealing for $20 \mathrm{hr}$ at $55^{\circ} \mathrm{C}$,

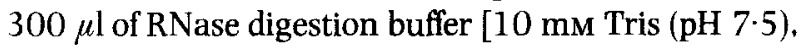
$5 \mathrm{~mm}$ EDTA, $300 \mathrm{~mm} \mathrm{NaCl}$, RNase A $\left(40 \mu \mathrm{g} \mathrm{ml}^{-1}\right)$, RNase T1 (1000 $\left.\mathrm{U} \mathrm{ml}^{-1}\right)$ ] was added to the hybridizations. The samples were incubated at room temperature for $1 \mathrm{hr}$. RNase digestion was terminated by the addition of $20 \mu \mathrm{l}$ of $10 \% \mathrm{SDS}$ and $50 \mu \mathrm{g}$ of proteinase $\mathrm{K}$ for $45 \mathrm{~min}$ at $37^{\circ} \mathrm{C}$. The samples were then extracted with phenol:chloroform and the RNA precipitated with ethanol. RNase resistant hybrids were fractionated on a denaturing $8 \%$ acrylamide, $8 \mathrm{~m}$ urea gel. Gels were dried and exposed to X-ray film at room temperature for 8 days.

\section{Retrograde Iabeling of Retinal Ganglion Cells}

Retinal ganglion cells were identified by retrograde transport of Fluoro-Gold (Fluorochrome Inc., Englewood, CO) or DAPI (4,6-diamidino-2-phenylindole, Sigma) injected into the brain (Perry, 1981). For identifying retinal ganglion cells in the 15-day-old embryo, retrograde labeling was performed in utero. Time-mated Sprague-Dawley rats were used for these expcriments. Embryonic day 1 (E1) is approximately $24 \mathrm{hr}$ after the vaginal plug was released. At E14, pregnant females were anesthetized with ether and the uterus surgically exposed. One microliter of a $1 \%$ Fluoro-Gold or $10 \mathrm{mg} \mathrm{ml}^{-1}$ DAPI solution in $\mathrm{H}_{2} \mathrm{O}$ was slowly injected through the uterus into the embryonic brain. Following the injection, incisions were sutured and the animals were allowed to survive an additional $24 \mathrm{hr}$ before being killed. Embryos were then isolated from the uterus, heads were removed, placed into fixative and processed as described above for in situ hybridization. Cells retrogradely labeled with tracers were visualized using a Zeiss Axiophot microscope equipped with fluorescent optics. Ganglion cells were identified as fluorescent cells residing in the appropriate anatomical laminae. Photomicrographs were taken and the coordinates of the slide recorded.

\section{Results}

Nicotinic AChR Gene Expression in the Adult Retina

In situ hybridization experiments and RNase protection assays were used to determine which members of the nAChR gene family were expressed in the adult retina, and the variety of retinal cells expressing these genes. Probes used to identify nAChR RNAs are shown in Fig. 1. In situ hybridizations showed that the $\alpha-3$, $\alpha-4, \beta-2, \beta-3$ and $\beta-4 \mathrm{nAChR}$ genes are expressed in the ganglion and inner nuclear cell layers of the adult rat retina (Fig. 2). The level of $\beta-4$ expression was consistently lower than the other nAChR genes studied. We were unable to obtain a reliable in situ hybridization signal with the $\alpha-2$ probe. Therefore, we used an RNase protection protocol to assay for the expression of the $\alpha-2$ gene (Fig. 3). The experiment showed that RNA isolated from adult retinas completely protected the $\alpha-2$ probe (excluding vector sequences), confirming its expression in the adult rat retina.

The rat's retinal ganglion cell layer is composed of both displaced amacrine and ganglion cells in about equal proportions (Perry, 1981). In this layer the $\alpha-3$ and $\beta-3$ genes were expressed by about $50 \%$ of the cells. In contrast, the other nAChR genes studied were expressed in over $70 \%$ of these cells and were therefore likely expressed by both ganglion and displaced amacrine cells.

The inner nuclear layer (INL) of the rat contains horizontal, bipolar, interplexiform, amacrine and displaced ganglion cells (Massey and Redburn, 1987; 


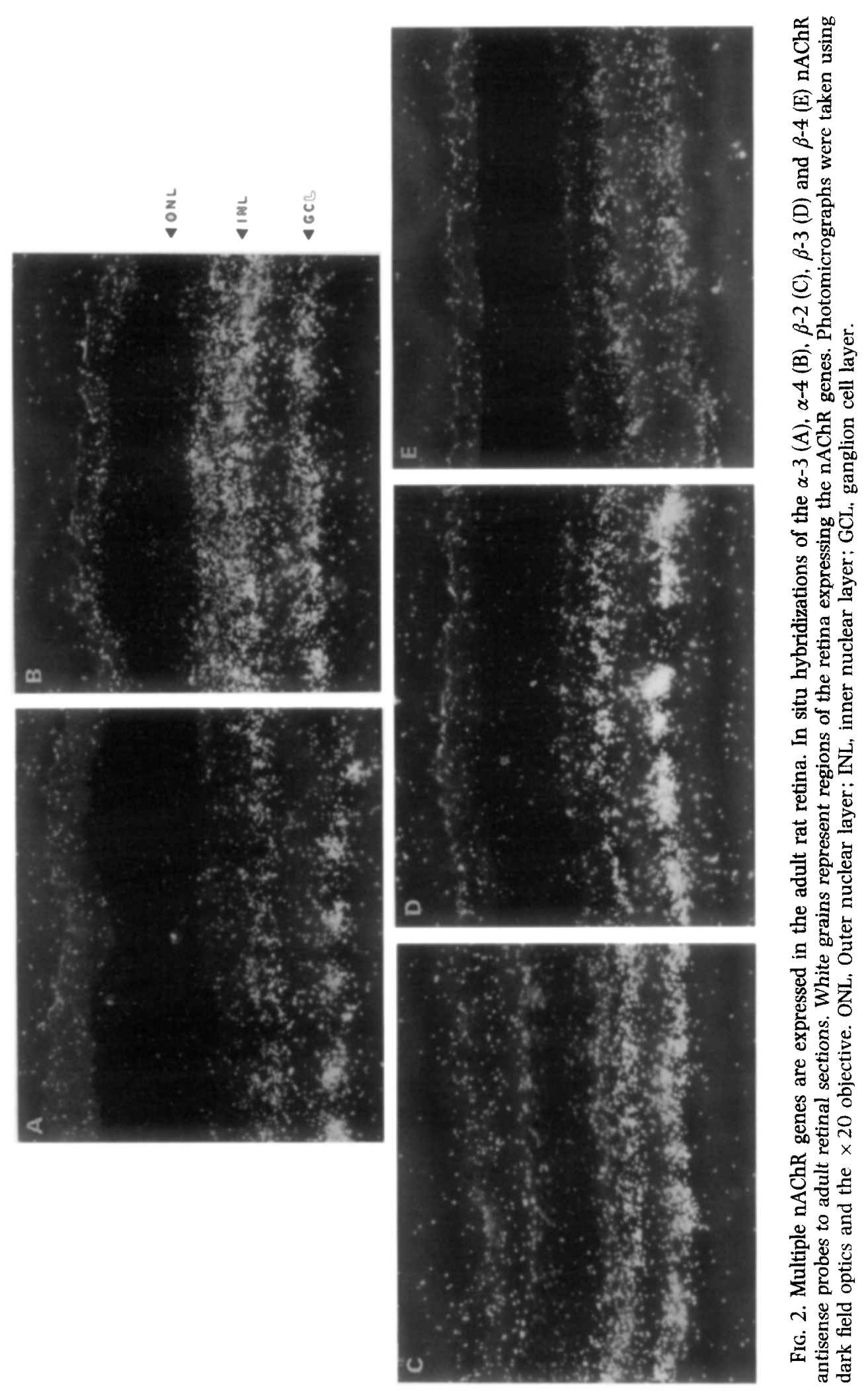




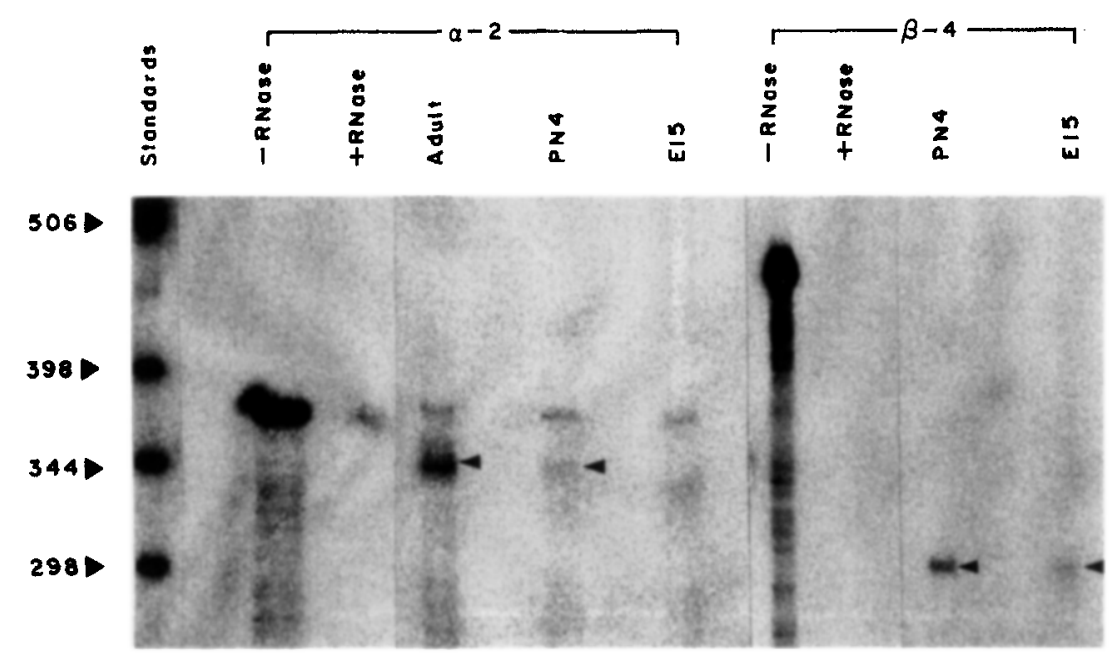

FIG. 3. Fxpression of the $\alpha-2$ and $\beta-4$ genes in the adult and developing retina. A 385 nucleotide radiolabeled $\alpha-2$ antisense RNA probe ( - RNase) was hybridized alone (+RNase) or used to hybridize with total RNA isolated from either, adult retinas $(40 \mu \mathrm{g})$. post-natal day 4 retinas $(78 \mu \mathrm{g})$ or E 15 retinas $(50 \mu \mathrm{g})$. This probe contained 35 nucleotides of vector sequence. A 438-nucleotide radiolabeled $\beta-4$ antisense RNA probe ( - RNase) was hybridized alone ( + RNase) or with total RNA isolated from post-natal day 4 retinas $(78 \mu \mathrm{g})$ and embryonic day 15 retinas $(25 \mu \mathrm{g})$. This probe contained 29 nucleotides of vector sequence. Following hybridization, the samples were digested with RNase (except those labelled - RNase) and those duplexes remaining were fractionated in a denaturing acrylamide gel. The dried gel was exposed to X-ray film without an intensifying screen for 8 days. The $\alpha-2$ probe is completely protected (excluding vector sequences), while the $\beta-4$ probe is only partially protected from RNase digestion by hybridization with retinal RNA. The partially protected $\beta-4$ probe is consistent with the $\beta-4$ transcript using a poly $(A)$ addition signal sequence about 100 nucleotides upstream of the reported poly (A) addition signal sequence (see Results). Arrowheads point to the protected regions of the probes. The left lane is a radiolabeled standard DNA ladder. The ladder was generated by restricting $\lambda$ DNA with EcoR I and Hind III, and subsequently end-labeling with [ $\left.{ }^{32} \mathrm{P}\right] \mathrm{dATP}$.

Liu and Jen, 1986). In this layer, in situ hybridizations consistently showed higher levels of $\alpha-4$ and $\beta-2$ RNA compared to $\alpha-3, \beta-3$ and $\beta-4$ RNA (Fig. 2). Except for $\alpha-4$ and perhaps $\beta-2$, the expression of these genes appears to be concentrated at the inner edge of the INL where amacrine cells reside (Masland et al., 1984; Vaney, 1985). Alpha-4 and $\beta-2$ expression occurs throughout the INL suggesting that, in addition to amacrine cells, other INL neurons express these genes (Fig. 2).

\section{Expression of $n A C h R$ Genes in the Developing Retina}

In order to gain insight into possible mechanisms by which retinal nAChR genes were induced, we assayed for nAChR gene expression in the developing retina. These experiments showed that nAChR genes were expressed in the embryonic retina at very early stages of development (Figs 4 and 5). At the earliest time examined (E13), we detected a low level of $\alpha-3$ and $\beta-4$ gene expression throughout the neuroblast layer (data shown for $\alpha-3$, Fig. 4). During the next 2 days of development (E14 and 15) we found a large induction in the level of expression of the $\alpha-3, \alpha-4, \beta-2, \beta-3$ and $\beta-4$ genes adjacent to the inner limiting membrane (data shown for $\alpha-3$ and $\beta-2$ in Figs 4 and 5). There was a central-to-peripheral gradient of expression, which correlates with the maturation gradient of retinal ganglion cells (Sidman, 1960; Morest, 1970).

In order to determine if these positive hybridizing ganglion cells had already sent their axons to the brain, we attempted to retrogradely label them by injecting DAPI into the embryonic brain. For this experiment DAPI was injected into the E14 brain. Twenty-four hours later retinas were isolated, sectioned and examined microscopically with fluorescent optics. This experiment showed that those ganglion cells residing at the inner limiting membrane of E15-16 day retinas have already sent their axons to the brain (Fig. 6).

By post-natal day 4 (PN4), the nAChR genes assumed a pattern of expression more like that seen in the adult retina. At this stage of development an inner plexiform layer has formed, separating the ganglion cell and inner nuclear layers. Nicotinic AChR gene expression in the inner nuclear layer was now obvious (Figs 4 and 5).

The presence of $\alpha-2$ and $\beta-4$ RNA in the developing retina was verified with RNase protection assays (Fig. 3). This experiment showed that RNA isolated from PN4 retinas completely protected the $\alpha-2$ probe (excluding vector sequences), while this RNA only partially protected the $\beta-4$ probe (i.e. approximately 300 nucleotides were resistant to RNase digestion out of 409 nucleotides contained in the probe, excluding vector sequences), confirming that these genes are expressed in the retina. Since the $\beta$-4 probe was generated from $3^{\prime}$ untranslated sequence, we thought it was likely that the partially protected probe resulted from the retinal $\beta-4$ transcript using a poly (A) addition signal sequence about 100 nucleotides upstream from the reported poly (A) addition signal sequence (Duvoisin et al., 1989). Inspection of the $\beta-4$ 3' untranslated sequence shows that another 

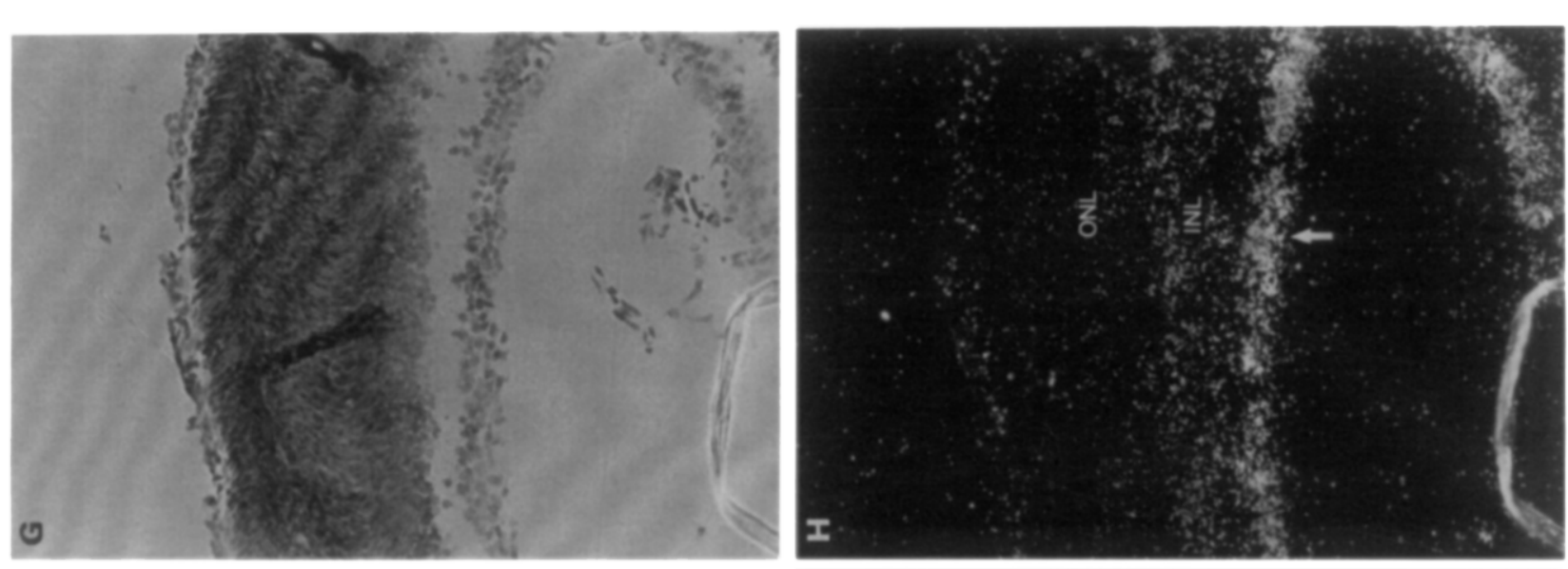

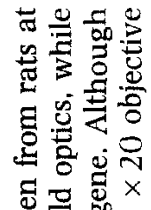

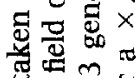

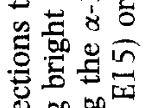

此

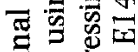

记

说

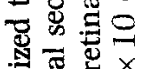

종
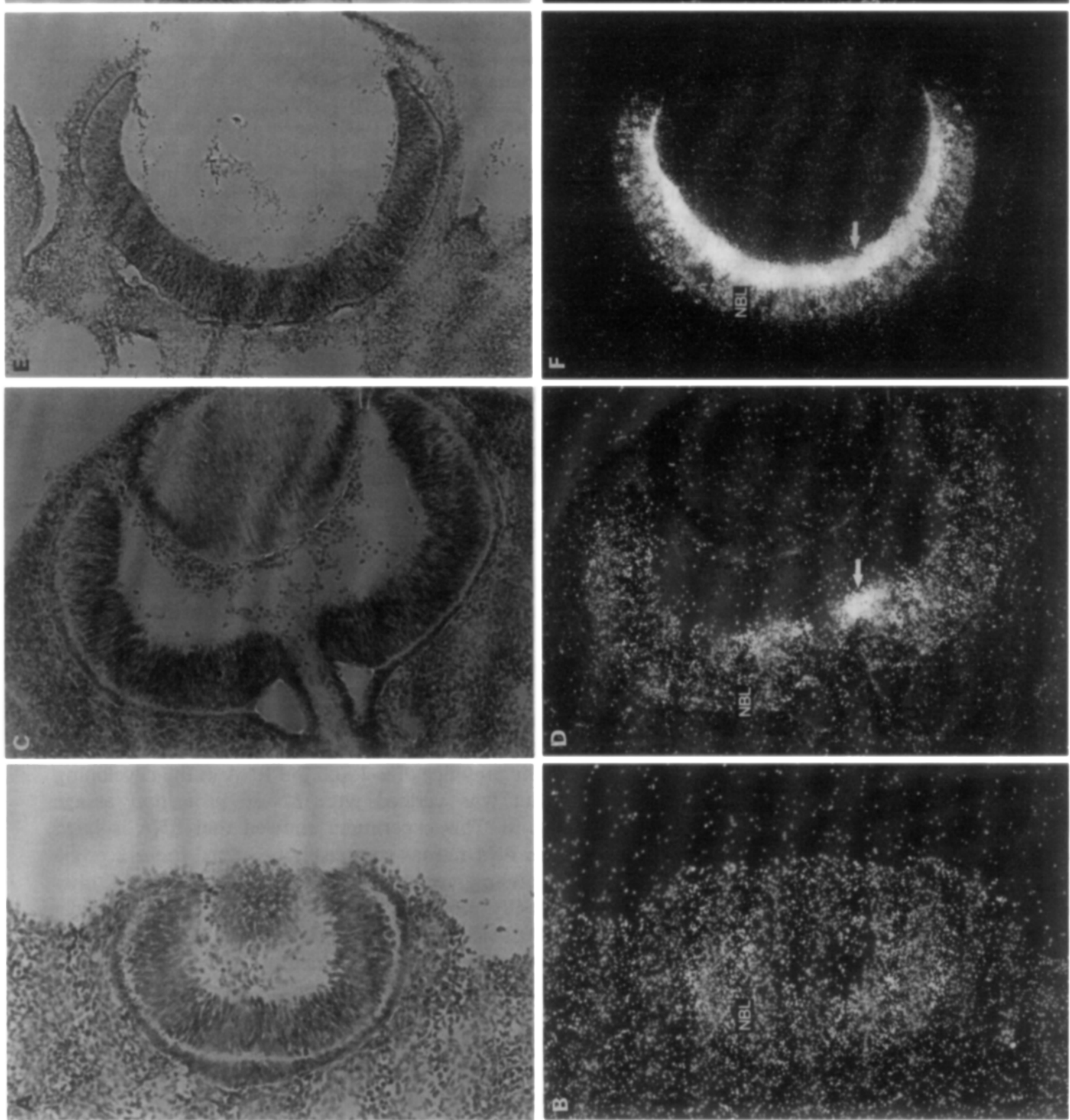

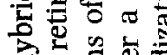

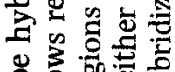

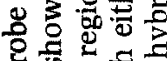

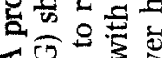

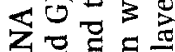
学害 되 ن웡 证

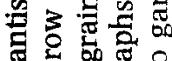
의

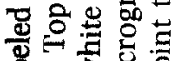

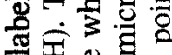
어용 要的要 它艺范 듕+윰혈

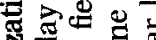
글 늘 要 吾古 존동

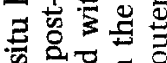

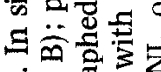
过范 政

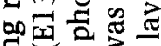

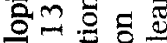

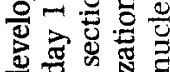
过焉

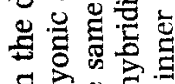
콘로록 믕르른 密㱐 员些志 정 몸

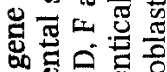
๓

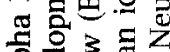
연 잉

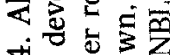

+ 息总气的方 

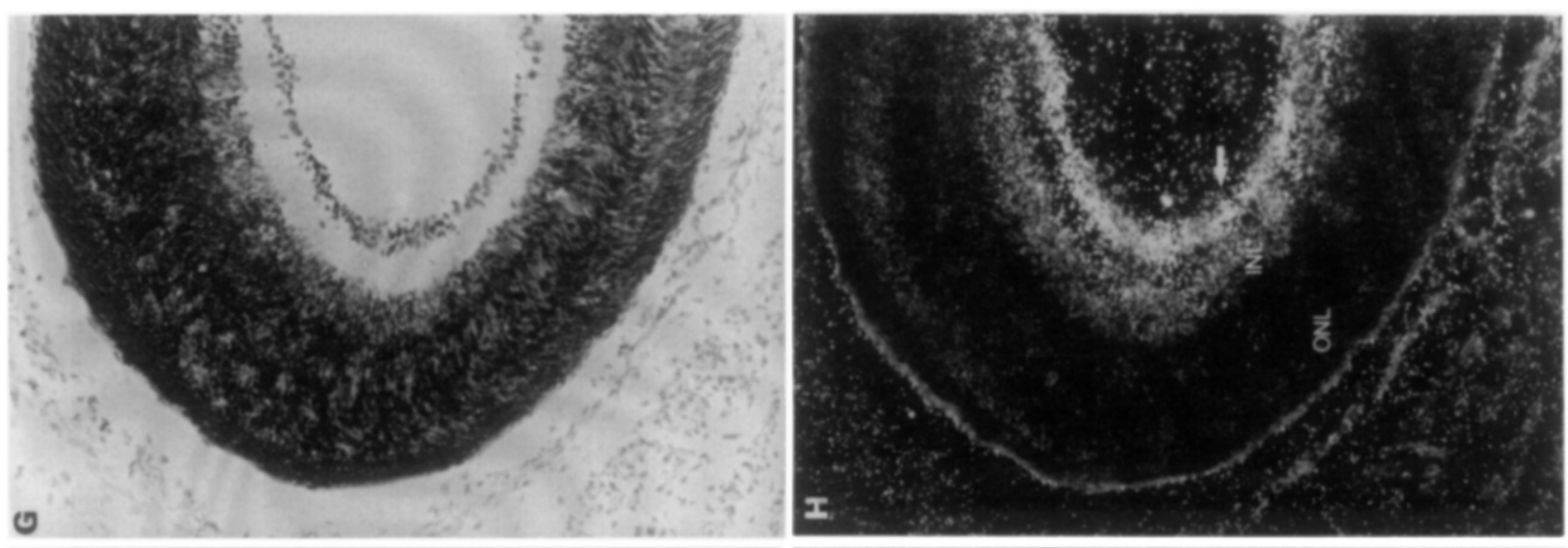

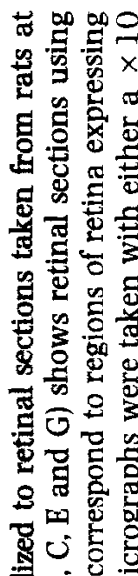
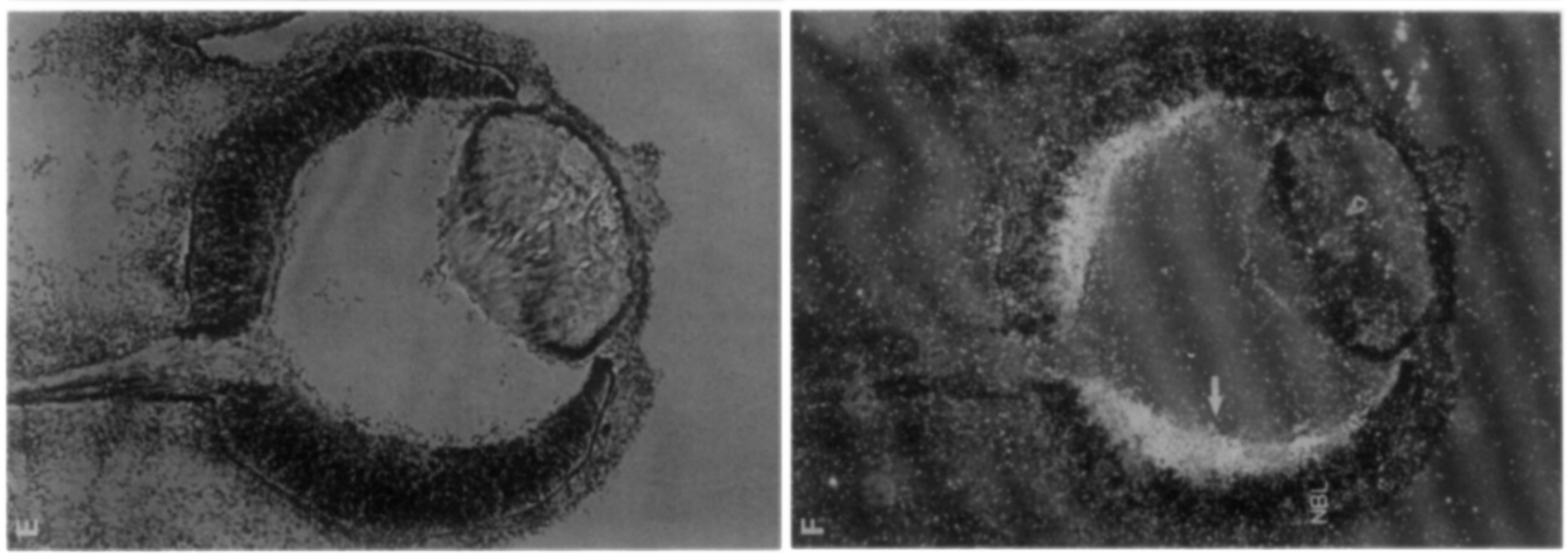

㛡的

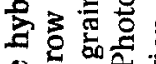

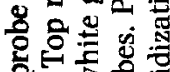

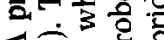

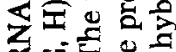

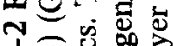

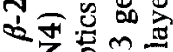

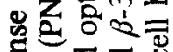

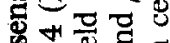

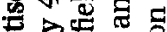

ส 뭄

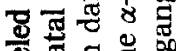

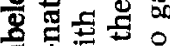

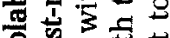

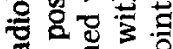

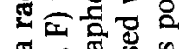
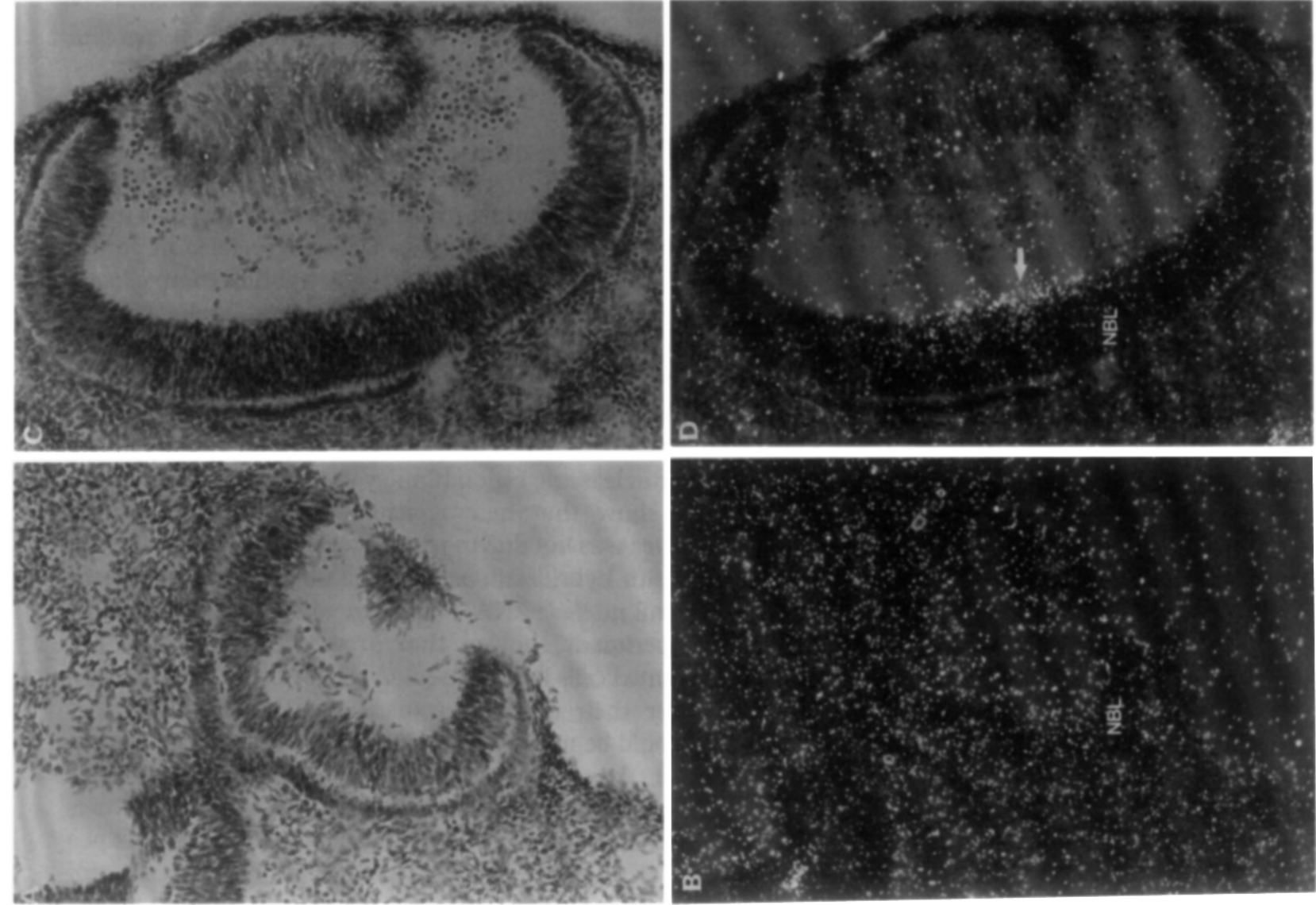

式过要食

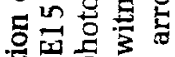

武言品

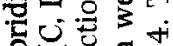
강 枟

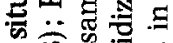
에의 廷要

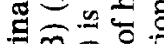
牙要 $\infty$ 를 敦政 定出 记 일 政 픙 论 : 홈 x क $x$ 풍 政 3

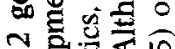
픙 형 要 的政贾 政

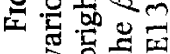




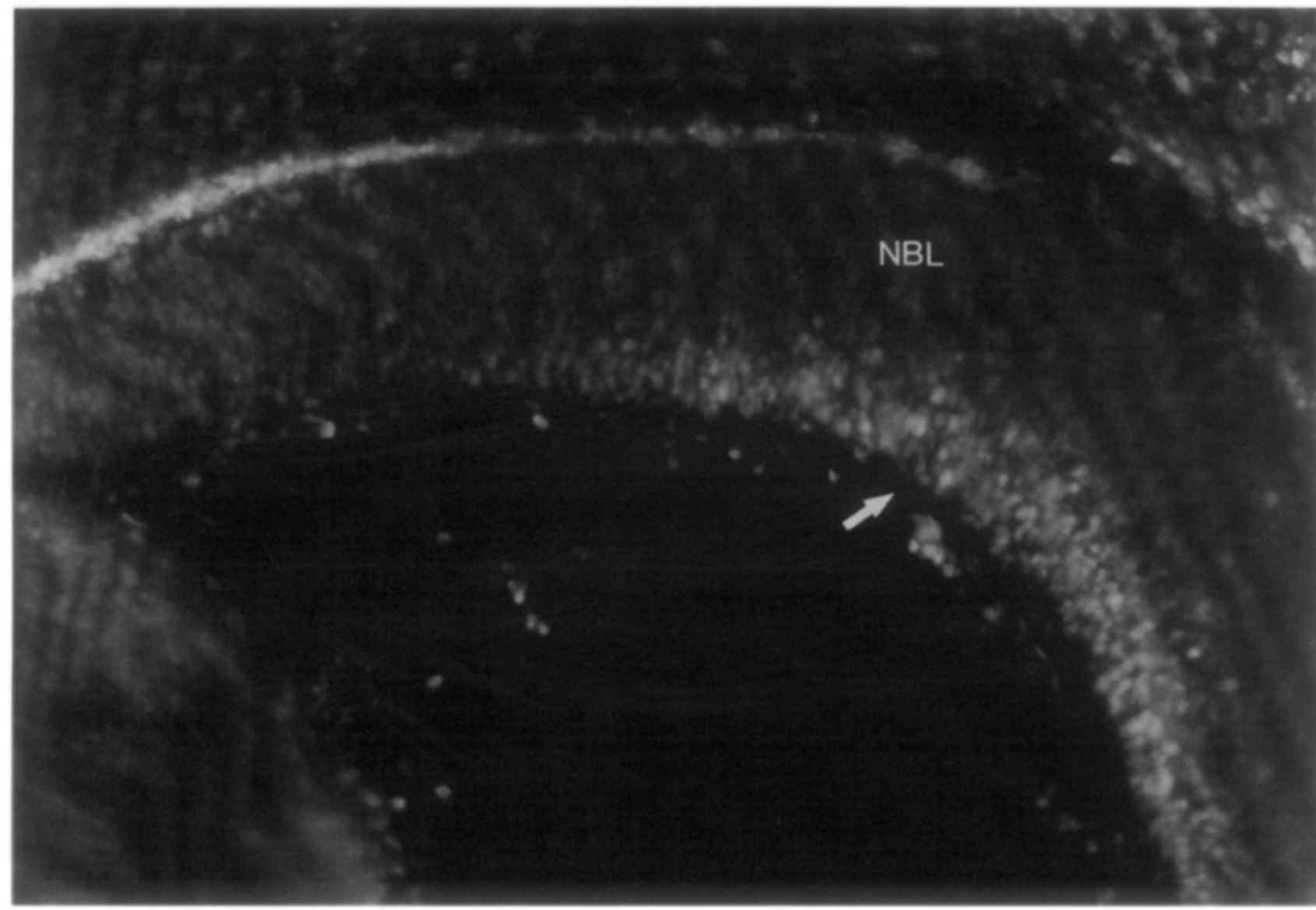

FIG. 6. Retrograde labeling identifies ganglion cells in the developing retina. The fluorescent tracer DAPI was injected into the brains of embryonic day 14 surgically exposed embryos. Twenty four hours later, retinas were fixed, sectioned and observed microscopically using fluorescent optics. Photomicrographs were taken using the $\times 20$ objective. The arrow points to ganglion cells that were backlabeled with DAPI. Abbreviations as in Fig. 4.

poly (A) addition signal sequence (Wickens and Stephenson, 1984) does exist in this region (nucleotide no. 2347; Duvoisin et al., 1989).

\section{Discussion}

In situ hybridization and RNase protection experiments showed that all the members of the nAChR gene family investigated were expressed in the adult rat retina (Figs 2 and 3). However, there were significant differences in the level and pattern of expression of these genes. These differences appeared to reflect the levels of retinal $\mathrm{nAChR}$ encoding RNAs and were not due to differences in probe, exposure times or regions of the retinas used. This is because all sections had a normalized amount of radioactivity, the probes were all of the same relative specific activity, and all the sections were exposed to emulsion for 4 days before developing. In addition, in situ hybridizations were performed many times on different retinal serial sections. Control hybridizations were done with sense orientation probes, which consistently showed only background levels of hybridization. Specificity of probes was confirmed by: (1) subunit specific hybridization to Southern blots of restricted
DNA corresponding to each of the nAChK clones using the same hybridization and post-hybridization conditions as were used for in situ hybridization experiments; (2) specific hybridization to brain regions previously shown to express these genes (Wada et al., 1989; Deneris et al., 1989; Duvoisin et al., 1989); and (3) nuclease protection assays showing even the most homologous nAChR RNA sequences are sensitive to nuclease digestion (Cauley et al., 1990). In addition, to show that heterogeneous expression of nAChR genes was not due to probe accessibility, we performed in situ hybridizations with the ubiquitously expressed small nuclear RNA, U1 (Howe and Steitz, 1986). This experiment showed that greater than $95 \%$ of the stained cells in the ganglion cell layer had silver grains over their cell bodies (data not shown). Finally, it should be noted that all the genes studied here, except $\beta-3$, have been shown to encode proteins that participate in functional ligand-gated ion channels (Deneris et al., 1989; Duvoisin et al.. 1989; Papke et al., 1989). That the $\beta-3$ gene product does not participate with any of the known $\alpha$-subunits in forming a functional nAChR may indicate its requirement for other undiscovered subunits in order to form a functional receptor. 


\section{nAChR Gene Expression in the Adult Retina}

All the nAChR genes examined in this report were found to be expressed by cclls in the ganglion and inner nuclear cell layers (Fig. 2). The ganglion cell layer is composed of both cholinergic amacrine cells and ganglion cells (Perry, 1981; Masland et al., 1984). Ganglion cells are known to express functional nAChRs that likely respond to input from cholinergic amacrine cells (Ariel and Daw, 1982a, b). In addition, ganglion cells express presynaptic nAChRs found on optic nerve terminals (Henley et al., 1986; Prusky and Cynader, 1988).

The expression of nAChR genes in the inner nuclear layer clearly shows a preference for those cells at the inner margin where amacrine cells reside (Fig. 2). There are many different types of amacrine cells, of which a small percentage are cholinergic (Massey and Redburn, 1987). Nicotinic acetylcholine receptor gene expression in the amacrine cell layer implies that besides providing input to ganglion cells, the cholinergic amacrine cells may also synapse with other amacrine cell types. In the goldfish and mouse retina such synapses have been documented (Pourcho, 1979; Zucker and Yazulla, 1982). In addition, it has been reported that cholinergic amacrine cells synapse with other cholinergic amacrine cells in rabbit. chick and goldfish retinas (Millar and Morgan, 1987), thus suggesting that these cells also express $n A C h R s$.

This latter report may help explain why we observed a majority of cells (over $70 \%$ ) in the ganglion cell layer expressing their $\alpha-4, \beta-2$ and $\beta-4$ nAChR genes. Since the ganglion cell layer is composed of about equal numbers of cholinergic amacrine and ganglion cells. one would predict a maximum of $50 \%$ of the cells in this layer to express their $\mathrm{nAChR}$ genes if confined to the ganglion cell type. However, if cholinergic amacrines can synapse with each other, one would expect them to contribute to the percentage of cells expressing nAChR genes in the ganglion cell layer. Confirmation of this possibility requires a double labeling protocol, in which nAChR RNA or protein is identified on a choline acetyltransferase positive amacrine cell.

Alpha- 4 and perhaps $\beta$-2 gene expression in the adult retina are unique in that they appear to be expressed in a region of the inner nuclear layer that harbors bipolar cells (Fig. 2). Although it is not clear that these cells synthesize functional nAChRs, there arc reports of $\alpha$-bungarotoxin binding on bipolar cells at amacrine-bipolar cell synapses (Pourcho, 1979; Zucker and Yazulla. 1982; James and Klein. 1985).

These data are consistent with immunohistochemical studies of nAChR expression in chick retina (Keyser et al., 1988) and indicate the ganglion cell and inner nuclear layers have the potential to synthesize a wide variety of different $\mathrm{nAChR}$ subtypes. This may reflect a differential subcellular distribution of these receptors, such as pre-, post- or extra-synaptic and/or it may reflect the functional heterogeneity of the cells expressing them. Although the potential number of differcnt types of $\mathrm{nAChRs}$ expressed in the retina is large, we have not been able to determine which combinations of $\mathrm{nAChR}$ subunit-encoding genes are expressed in any one particular cell.

\section{nAChR Gene Expression During Retinal Development}

At the earliest time investigated (E13), we detected a low level of $\alpha-3$ and $\beta-4$ gene expression throughout the developing retina (Fig. 4). At this time of development the majority of cells are undifferentiated (Sidman, 1960; Braekevelt and Hollenberg, 1970). The significance of expressing $n A C h R$ genes at this early stage of development is not known, however, like nAChRs expressed throughout embryonic muscle fibers (Jaramillo, Vicini and Schuetze, 1988), they may be playing a physiological role independent of synaptic communication. Around E14 there is a coordinate induction of $\mathrm{nAChR}$ gene expression along the inner limiting membrane (Figs 4 and 5). Retrograde labeling studies using dyes injected into the embryonic brain at E14 show the cells expressing these genes are retinal ganglion cells that have already sent their axons to the brain (Fig. 6). It is interesting to note that the high level of E1 5 nAChR gene expression is concentrated at the inner wall of the retina over ganglion cell bodies. Clearly, ganglion cells are being born at the ventricular surface, yet we failed to detect any cells which express their nAChR genes at a level comparable to those which have reached their final position.

Two likely mechanisms exist to explain the induction of the nAChR genes at E14-15. First, a target derived factor retrogradely transported back to the ganglion cell body may be responsible for inducing nAChR gene expression. It is important to emphasize that this does not suggest that a synaptic connection is required, but rather a factor released by the target is picked up by retinal axon terminals. Consistent with this hypothesis is our finding that those ganglion cells expressing their $\mathrm{nAChR}$ genes correspond to cells that can be retrogradely labeled by injection of dye into the embryonic brain (Fig. 6). Alternatively, it is conceivable that the induction of $\mathrm{nAChR}$ gene expression in these ganglion cells is in response to an environmental cue at the inner limiting membrane. An environmental effect appears to be important in detcrmining differentiation of many retinal cells (Adler and Hatlee, 1989; Reh and Kljavin, 1989). Consistent with both hypotheses is the observation that only those ganglion cells at the inner limiting membrane in E14 or E1 5 embryos express their nAChR genes at a relatively high level (Figs 4 and 5). Regardless which of the above mechanisms is correct it is interesting that patch clamp studies of dissociated retinal ganglion cells in culture showed the majority of these cells to have a single conductance of approximately $48 \mathrm{pS}$ in response to acetylcholine (Lipton et al.. 1987). Yet we 
show here that these cells have the potential to synthesize many types of $\mathrm{nAChR}$, and others have demonstrated that different combinations of nAChR subunits can combine to form functional channels with different conductances (Papke et al., 1989). It is possible that ganglion cell-target interactions or the environment the cells reside in are crucial for maintaining $\mathrm{nAChR}$ gene expression and that dissociated retinal cells no longer express many of their nAChR genes.

Between E18 and PN4 the ganglion cell layer separates from the neuroblast layer and we begin to detect $\mathrm{nAChR}$ gene expression in what will become the inner nuclear layer (Figs 4 and 5). The apparent decrease in gene expression of the adult versus the embryonic ganglion cell layer is probably due, in a large part, to cell death which occurs throughout this time period (Potts, Dreher and Bennett, 1982).

In summary, these data show that: (1) the $\alpha-2$, $\alpha-3, \alpha-4, \beta-3$, and $\beta-4$ nAChR subunit-encoding genes are expressed in the rat retina; (2) these genes are coordinately induced in ganglion cells beginning about embryonic day 14; and (3) multiple retinal cell types express these nAChR genes in both the ganglion and inner nuclear cell layers.

\section{Acknowledgements}

We thank Dr Pamela Raymond and the members of the Goldman lab for critically reading this manuscript. We also thank M. Elizabeth Cox for assistance with word processing. This work was supported by a grant from the Lucille P. Markey Charitable Trust to D. Goldman.

\section{References}

Adler, R. and Hatlee, M. (1989). Plasticity and differentiation of embryonic retinal cells after terminal mitosis. Science 243. 391-3.

Ariel, M. and Daw, N. W. (1982a). Effects of cholinergic drugs on receptive tield properties of rabbit retinal ganglion cells. J. Physiol. 324, 135-60.

Ariel, M. and Daw, N. W. (1982b). Pharmacological analysis of directionally sensitive rabbit retinal ganglion cells. J. Physiol. 324, 161-85.

Barnstable, C. J. (1987). A molecular view of vertebrate retinal development. Mol. Neurobiol. 1, 9-45.

Boulter, J., Connolly, J., Deneris, E., Goldman, D., Heinemann, S. and Patrick, J. (1987). Functional expression of two neuronal nicotinic acetylcholine receptors from cDNA clones identifies a gene family. Proc. Natl. Acad. Sci. U.S.A. 84, 7763-7.

Boulter, J., Evans, K., Goldman, D., Martin, G., Treco, D., Heinemann, S. and Patrick, J. (1986). Isolation of a CDNA clone coding for a possible neural nicotinic acetylcholine receptor $\alpha$-subunit. Nature 319, 368-74.

Braekevelt, C. R. and Hollenberg, M. J. (1970). The development of the retina of the albino rat. Am. J. Anat. 127, 281-302.

Cauley, K., Agranoff, B. W. and Goldman, D. (1989). Identification of a novel nicotinic acetylcholine receptor structural subunit expressed in goldfish retina. J. Cell. Bivl. 108, 637-45.

Cauley, K., Agrano: , B. W. and Goldman, D. (1990). Multiple nicotinic acetylcholine receptor genes are expressed in goldfish retina and tectum. I. Neurosci. 10 , 670-83.

Chirgwin, J. M., Przybyla, A. E., MacDonald, R. J. and Rutter, W. J. (1979). Isolation of biologically active ribonucleic acid from sources enriched in ribonuclease. Biochemistry 18, 5294-9.

Cox, K. H., Del eon, D. V., Angerer, I. M. and Angerer. R. C. (1984). Detection of mRNAs in sea urchin embryos by in situ hybridization using asymmetric RNA probes. Dev. Biol. 101, 485-502.

Deneris. E. S., Boulter, J., Swanson, L. W., Patrick, J. and Heinemann, S. (1989). $\beta 3$ : A new member of nicotinic acetylcholine receptor gene family is expressed in brain J. Biol. Chem. 264, 6268-72.

Deneris, E. S., Connolly, J., Boulter, J., Wada, E., Wada, K. Swanson. L. W., Patrick, J. and Heinemann. S. (1988). Primary structure and expression of $\beta 2$ : a novel subunit of neuronal nicotinic acetylcholine receptors. Neuron 1. 45-54.

Duvoisin, R. M., Deneris, E. S., Patrick. J. and Heinemann, S. (1989). The functional diversity of the neuronal nicotinic acctylcholine receptors is increased by a novel subunit: $\beta 4$. Neuron 3, 487-96.

Goldman, D., Boutler, J., Heinemann. S. and Patrick, J. (1985). Muscle denervation increases the levels of two mRNAs coding for the acetylcholine receptor $\alpha$-subunit. J. Neurosci. 5, 2553-8.

Goldman. D., Deneris, E., Luyten, W., Kochhar, A., Patrick, J. and Heinemann, S. (1987). Members of a nicotinic acetylcholine receptor gene family are expressed in different regions of the mammalian central nervous system. Cell 48, 965-73.

Henley, J. M., Lindstrom, J. M. and Oswald, R. E. (1986). Acetylcholine receptor synthesis in retina and transport to optic tectum in goldfish. Science 232, 1627-9.

Holt. C. E., Bertsch. T. W., Ellis, H. M. and Harris. W. A. (1988). Cellular determination in the xenopus retina is independent of lineage and birth date. Neuron 1. 15-26.

Howe, J. G. and Steitz, J. A. (1986). Incalization of EpsteinBarr virus-encoded small RNAs by in situ hybridization. Proc. Natl. Acad. Sci. U.S.A. 83, 9006-10.

James, W. A. and Klein, W. L. (1985). $\alpha$-Bungarotoxin receptors on neuron isolated from turtle retina: molecular heterogeneity of bipolar cells. J. Neurosci. 5, 352-61.

Jaramillo, F., Vicini, S. and Schuetze, S. M. (1988). Embryonic acetylcholine receptors guarantee spontaneous contractions in rat developing muscle. Nature 335. 66-68.

Keyser, K. T., Hughes, T. E., Whiting, P. J., Lindstrom, J. M. and Karten. H. J. (1988). Cholinoceptive neurons in the retina of the chick: an immunohistochemical study of the nicotinic acetylcholine receptors. Vis. Neurosci. 1. 349-66.

Liu, Z. and Jen, L. S. (1986). Displaced retinal ganglion cells in normal rats and rats with one eye enucleated at birth. Neurosci. Letts. 3, 239-44.

Leutje. C. W., Patrick, J, and Seguela, P. (1990). Nicotine receptors in the mammalian brain. FASEB J. 4, 2753-60.

Lipton, S. A., Aizenman, E. and Loring, R. H. (1987). Neural nicotinic acetylcholine responses in solitary mammalian retinal ganglion cells. Pflügers Arch. 410, 37-43.

Masland, R. H., Mills, J. W. and Hayden, S. A. (1984). Acetylcholine-synthesizing amacrine cells: identification and selective staining by using radioautography and fluorescent markers. Proc. R. Soc. Lond. 223. $79-100$.

Massey, S. C. and Redburn, D. A. (1987). Transmiller circuits in the vertebrate retina. Prog. Neurobiol. 28. $55-96$. 
Matter, J., Matter-Sadzinski, L. and Ballivet, M. (1990). Expression of neuronal acetylcholine receptor genes in the developing chick visual system. EMBO J. 9, 1021-6.

Millar, T. J. and Morgan, I. G. (1987). Cholinergic amacrine cells in the rabbit retina synapse onto other cholinergic amacrine cells. Neurosci. Letts. 74, 281-5.

Morest, D. K. (1970). The pattern of neurogenesis in the retina of the rat. Z. Anat. Entwickl.-Gesch. 131, 45-67.

Papke, R. L., Boulter, J., Patrick, J. and Heinemann, S. (1989). Single-channel currents of rat neuronal nicotinic acetylcholine receptors expressed in xenopus oocytes. Neuron 3, 589-96.

Perry, V. H. (1981). Evidence for an amacrine cell system in the ganglion cell layer of the rat retina. Neurosci. 6, 931-44.

Potts, R. A., Dreher, B. and Bennett, M. R. (1982). The loss of ganglion cells in the developing retina of the rat. Dev Brain Res. 3, 481-6.

Pourcho, R. G. (1979). Localization of cholinergic synapses in mammalian retina with peroxidase-conjugated $\alpha$ bungarotoxin. Vision Res. 19, 287-292.

Prusky, G. T. and Cynader, M. S. (1988). $\left[{ }^{3} \mathrm{H}\right]$ nicotine binding sites are associated with mammalian optic nerve terminals. Vis. Neurosci. 1, 245-8.

Reh, T. A. and Kljavin. I. J. (1989). Age of differentiation determines rat retinal germinal cell phenotype induction of differentiation by dissociation. J. Neurosci. 9. 4179-89.

Sidman. R. L. (1960). Histogenesis of mouse retina studied with thymidine- $\mathrm{H}^{3}$. In The Structure of the Eye (Ed. Smelse, G. K.). Pp. 487-506. Academic Press, Inc: New York.

Swanson. L. W., Simmons, D. M., Whiting, P. J. and Lind- strom, J. (1987). Immunohistochemical localization of neuronal nicotinic receptors in the rodent central nervous system. J. Neurosci. 7, 3334-42.

Turner, D. L. and Cepko, C. L. (1987). A common progenitor for neurons and glia persists in rat retina late in development. Nature 328, 131-6.

Turner, D. L., Snyder, E. Y. and Cepko, C. L. (1990). Lineageindependent determination of cell type in the embryonic mouse retina. Neuron 4, 833-45.

Vaney, D. I. (1985). The morphology and topographic distribution of A II amacrine cells in the cat retina. Proc. R. Soc. Lond. B244, 475-88.

Wada, K., Ballivet, M., Boulter, J., Connolly, J.. Wada, E., Deneris, E. S., Swanson, L. W., Heinemann, S. and Patrick, J. (1988). Functional expression of a new pharmacological subtype of brain nicotinic acetylcholine receptor. Science 240, 330-4.

Wada, E., Wada, K., Boulter, J., Deneris, E., Heinemann, S., Patrick, J. and Swanson. L. W. (1989). Distribution of alpha-2, alpha-3, alpha-4, and beta-2 neuronal nicotinic receptor subunit messenger-RNAs in the central nervous system - a hybridization histochemical study in the rat. J. Comp. Neurol. 284, 314-35.

Wetts, R. and Fraser, S. E. (1988). Multipotent precursors can give rise to all major cell types of the frog retina. Science 239, 1142-5.

Wickens, M. and Stephenson, P. (1984). Role of the conserved AAUAAA sequence: four AAUAAA point mutants prevent messenger RNA 3 ' end formation. Science 226, 1045-51.

Zucker, C. and Yazulla. S. (1982). Localization of synaptic and nonsynaptic nicotinic-acetylcholine receptors in goldfish retina. J. Comp. Neurol. 204, 188-95. 